\title{
“Common Sense Geography” and the Elected Official: Technical Evidence AND Conceptions of 'TRust' in TORON- TO’s GARDINER EXPRESSWAY DECISION ${ }^{1}$
}

\author{
PATRICK WATSON
}

\begin{abstract}
In fields such as Sociology and Political Science, there have been, over the course of three decades, attempts to engage elected officials in "EvidenceBased Decision-Making". Evidence is generally conceived as "expert" advice provided to politicians. A question that has gained more centrality in recent years is "why do elected officials not trust expert opinion or technical evidence?" and the answer to this question has been sought in historical or general terms (e.g. Irwin 2006; Weiss et al. 2008; Kraft et al. 2015). Here I will propose an alternative question: "when politicians exhibit a lack of trust in expert advice, how is such skepticism publicly accounted for?" I will examine this question by utilizing a case study ethnographic approach to the City of Toronto's controversial decision to endorse the Hybrid alternative for the Gardiner expressway. By doing so, I intend to show that knowledge controversies are not inherently a form of deficiency on the part of the elected official - that they are ignorant to the implications of evidence - but rather the standard by which elected officials and appointed experts review and understand evidence can lead to very different (although both reasonably 'correct') conclusions.
\end{abstract}

Keywords: Public Policy; Evidence; Knowledge Sociology; Ethnomethodology

Résumé. Des disciplines comme la sociologie et la science politique tentent depuis trois décennies de susciter l'intérêt de personnes élues pour la « prise de décisions fondée sur des données probantes ». On entend généralement par données probantes des conseils d'experts fournis aux personnalités politiques. Ces dernières années, on accorde une place de plus en plus centrale à la question de

1. Earlier drafts of this paper were presented at York University's Science and Technology Studies Program invited speakers series and the 2014 Canadian and American Sociological Association meetings. I would like to thank Philip Walsh, Aryn Martin, K. Neil Jenkings, Peter Eglin and Wes Sharrock for their comments on earlier drafts. This draft was greatly enhanced by the two anonymous reviewers, and I thank them as well. 
savoir " pourquoi les personnes élues ne font-elles pas confiance aux opinions d'experts ou aux données probantes techniques ?», question à laquelle on a tenté de répondre de manière historique ou générale (p. ex., Irwin, 2006; Weiss et al. 2008; Kraft et al. 2015). Dans cet article, je propose une autre question : « quand les personnalités politiques font preuve d'un manque de confiance à l'égard des conseils d'experts, comment cette méfiance est-elle publiquement justifiée ? " Je vais aborder cette question à l'aide d'une étude de cas ethnographique de la décision controversée par la Ville de Toronto d'appuyer la solution dite hybride pour l'autoroute Gardiner. Ainsi, je compte démontrer que des controverses des connaissances ne témoignent pas en soi d'une forme de lacune chez une personne élue - que celle-ci ignore ce que signifient les données probantes mais plutôt que les critères selon lesquels les personnalités élues et les experts désignés évaluent et comprennent les données probantes peuvent mener à des conclusions différentes (bien que toutes deux raisonnablement « justes »).

Mots clés: Politique publique; Preuve; Sociologie de la connaissance; Ethnométhodologie.

\section{INTRODUCTION}

F'or over 30 years, sociologists of science and technology and political scientists have exhibited interest in integrating or understanding scientific and technical models of information evaluation and planning in public policy debates. Generally glossed as "Evidence Based Decision-Making" (henceforth EBDM) these scholars address a disparate and unsystematic mass of techniques attempting to resolve perceived inefficiencies for decision-making in government (in political science see for example: Aucoin, 1990; Young et al. 2002; Head, 2008; Winch \& Maytonera, 2009; Monahan 2010; Boehm et al. 2013. In STS see: Knorr 1976; Porter 1995; Wynne 1996; Epstein 1996; Collins and Evans 2002; 2007; Jasanoff 2004; Lynch and Cole 2005; Pielke 2007 Collins 2014a; 2014b). These discussions provide an interesting backdrop for understanding societal institutions such as democratically elected governments, particularly when knowledge controversies (Jasanoff 2004; Whatmore 2009) - friction between "expert advisors" and elected officials - emerge. A contemporary example of such a knowledge controversy event is Toronto City Council's decision to adopt the Hybrid model for the easternmost 2.4 kilometers of the Gardiner Expressway. In this case, Toronto City Council chose to disregard the professional advice of the city's chief planner, a consortium of ex-chief planners, and to a significant degree the very experts they had appointed to assist in deciding how to treat the ailing expressway. 
One way we might be tempted to treat the knowledge controversy pertaining to the Gardiner is to reduce the obligations of the elected official to a form of "passive recipient" of "expert" advice, and question: "what aspect of these discussions did elected officials not understand when they chose to ignore or mistrust the experts?" This could reflect the vast majority of public discourse and media scrutiny pertaining to knowledge controversies in general or the Gardiner decision in particular. However, doing so presupposes at least two things; the first, that it is properly the role of the elected official to trust expert advice, as opposed to actively scrutinize evidence. There has recently been an emphasis in scholarship on expert advice for political decision-making in which it is presumed that expert advice is naturally good advice (i.e. Collins and Evans 2002; 2007; Nyholm and Haveri 2009; Winch and Maytorena 2009; Collins 2010; 2014a; Smallman 2014). This leads to the second presupposition, that the 'expert' and the elected official are engaged in the same 'constitutive practice' (Garfinkel 1963; Watson 2009) - deriving and accepting systematic evidence (in all of its various forms) for public policy decision-making - whereby choosing to disagree with an expert is, in a sense, a breach of trust. When this attitude to the relationship between 'expert' and elected official is undertaken (that they are engaged in the same practice, applying technical or scientific findings or guidance to public policy decisions) then as controversies emerge between experts and elected officials ground is opened for the accusation of ineptitude leveled at the elected official when they exhibit mistrust for what the expert has told them - "they are not the expert, the expert(s) gave them the best advice, why did they not simply accept that advice?"

This approach imposes a normative frame upon political decisionmaking where elected officials are understood as deficient in some manner when they do not accept the advice of appointed experts - that they are "ideological," "ignorant of the export of official/technical/scientific evidence," "not listening to the right experts," etc... An alternative way to examine knowledge controversies between experts and elected officials is to ask: "when elected officials exhibit a lack of trust in the advice of their appointed experts, under what conditions does that mistrust make sense?" Applying this approach to the Gardiner decision, I argue, shows that it is not the case that political officials are deficient in decision-making skills, "scientific" or "technical" knowledge, or perceptions of expertise or appointments to the roles governed by expertise. Instead, their orientations to the vernacular presentations of data, evidence, information, etc. does not unproblematically reflect those of experts (c.f. Vaughan 1996; 2006). As a result, elected officials are not necessarily being ignorant of expert, technical, or scientific advice when exhibiting a mistrust, and that over- 
simplifying the interaction between elected officials and experts as such leads to impoverished understandings of the role of evidence and expertise in public policy decision-making.

\section{Structure of the Article}

I will begin by introducing the history of the Gardiner Expressway and the decision-making process involved in setting its future. I will discuss the method for devising future scenarios (roadway paths) that appointed experts (city staff and hired consultants) presented to elected officials while making their decision, and the reception these scenarios received before council. In particular, I will analyze a speech given by Toronto Mayor John Tory on May $12^{\text {th }}, 2015$, through which he expressed his support for the Hybrid alternative. Doing so runs the risk of furnishing the perception that Mr. Tory was singly responsible for the Gardiner decision, and under-represents the complex assemblages of opinions, perspectives and relationships of either expertise or democratic accountability otherwise pertinent to this discussion. I suggest Mr. Tory's speech should be read as an amalgam of the various expressions of skepticism and doubt shared by the twenty-four Toronto city councilors who voted in support of the Hybrid, as opposed to a definitive account of how this decision was arrived at. Rather than a synopsis of the "complete" decision, Mr. Tory's speech stands as a concise and readily available account of the publicly presented reasons ${ }^{2}$ exhibited for arriving at the conclusion that the expert-derived report did not stand up to the scrutiny of elected officials. Readers who are interested in expressions beyond Mr. Tory's speech may refer to the vast collection of news media articles in which various other councilor's opinions were publicized. Secondly, Mr. Tory, in making this speech, and especially doing so at the time he did, cast himself very much front and center in the Gardiner debate, a position that is likely fitting for the Mayor in such a significant policy decision. All the same, Mr. Tory's

2. Complicating reasons in public policy decision-making is the presumption that such things are and can be publicly available. To be clear, I do not assume that the reasons presented in Mr. Tory's speech are real or genuine reasons, so much as an account or justification for public consumption. Elected officials may have various reasons for making whatever public policy decisions they arrive at, some of which may be accounted for publicly and others that may either be withheld or never fully enumerated by the elected official in question (i.e. "it just didn't feel right" or other such "gut instinct" type responses, or more nefarious and secret reasons). For further discussion on the accessibility of reasons for sociological scrutiny, see Blum and McHugh (1971). 
speech should be treated as exemplary of the twenty-four councilors who supported the Gardiner Hybrid option, as opposed to determinate.

Finally, I will use the ethnomethodological notion of common sense geography to demonstrate how the decision to support the Hybrid alternative can be understood as 'evidence-based' despite the conclusions politicians drew through that evidence running contrary to the conclusions of appointed experts. In so doing, I will utilize Garfinkel's discussion of trust (1963; see also Watson 2009) to illustrate how, at least in the Gardiner case, as well as perhaps others, the knowledge controversy is not derived from states of knowing and ignorance, but rather the degree of certainty one is willing to grant evidence presented to inform this decision.

\section{A Brief Note on Methodology}

On a cautionary note, although this article attests to an "ethnographic" perspective on publicly accountable reasons exhibited by elected officials for mistrusting expert advice on the Gardiner, I claim no special access to decision-makers. Rather than contributing to the emerging field of ethnographic inquiry (close and long term, behind-the-scenes observation) of elected officials at work (c.f. Rhodes 2005; Yannow 2006; van Hulst 2008) my interests are purely aligned with inquiry in the 'anthropology of choice' initially proposed by Hacker (2007) although more recently, and pertinent to this work, discussed by Harper, Randall and Sharrock (2016). If we take it that our task is to make sense of how a decision was made, then our methods for doing so will rely heavily on what traces such decisions leave behind. While I began to attend to the Gardiner meetings in February 2014, as the first report on the Gardiner reached Toronto City Council's Public Works and Infrastructure Committee (PWIC), my direct observations of the process (including attending various council meetings, public consultations, analysis of documents and evidence from reports dating back to 1990, reviewing news media contributions, interviewing consultants, city staff, consultation exercise attendees, etc...) have little to do with the analysis presented here except inasmuch as they have contributed to my background knowledge of the Gardiner. Instead, here I hope to focus exclusively on accounts of reasoning presented through the deliberative process such that we might answer the question: "despite this decision not conforming with the advice of experts, how can it be seen to make-sense?" To accomplish this, I have reviewed how city council's staff and consultants created the evidence for this report, and the formal or official presentations of dissent from expert opinion. The 
article does not seek to add new information to the Gardiner debate, but rather to examine how this decision was, in effect, explained to the public, i.e. following in the philosophical and sociological tradition initially extolled by Peter Winch (1958).

\section{Background: The Gardiner Decision}

In 2016, the Gardiner Expressway, an at-grade and elevated highway running 18-kilometers along Toronto's shoreline with Lake Ontario, reached the end of its functional lifespan. The 50-year expectancy was a product of design and construction technology available when the Gardiner was built between 1955 and 1966. In 2012 a number of incidents of concrete falling 20 meters from the elevated portion onto Lake Shore Boulevard below - in one case striking a private vehicle - underscored the need for urgent action by Toronto City Council to do something about the aging expressway (Church 2013; Slaughter and Hasham 2012).

\section{The Environmental Assessment}

In 2008, Toronto City Council commissioned an Environmental Assessment (EA) report to be conducted by city staff in conjunction with (among others) Dillon Consulting, a firm that specializes in transportation modeling and planning. The EA is a technical document used to evaluate alternative options for the roadway and communicate the proposed and adopted plans to the Ontario provincial government's Ministry of Environment and Climate Change (MoECC). It is a technical document on the grounds that it uses formal, explicated (c.f. Collins 2010) techniques to compare the proposed alternatives to the current Gardiner against a constant set of future parameters. The EA was used to specifically evaluate the most deteriorated portion of the Gardiner, the easternmost 2.4 kilometers stretching between Jarvis Street and the Don Valley Parkway (DVP). This was also politically significant, as the area under the Gardiner at its junction with the DVP is a site of proposed urban renewal and regeneration. Addressing this stretch of the Gardiner will have a knock-on effect on how the Don River-mouth regeneration plans proceed.

The EA was accomplished in part using an industry-standard transportation modeling scenario software, PARAMICs, which overlays current data the city has collected on commuting and travel patterns with a professionally established future scenario built out, in this case, to the year 2031, when Toronto's Don River Revitalization Project is expected to reach completion. PARAMICs was used to model four dif- 
ferent options for the Gardiner: Maintain, Improve, Replace and Remove. Each model was tested against a consistent future devised by a panel of professionals with ascribed expertise in transport planning and modeling at Dillon Consulting. From these models, city staff and consultants were able to estimate private vehicle commute time differences during the peak morning rush hour among the different road layout options. These differences showed that typical commutes would increase by ten-minutes (in the 2014 report) or three-minutes (in the 2015 report) if the Remove option were chosen over the options that maintained an expressway system. It was these projections that took on a central role in political scrutiny of the EA process (to be discussed below).

The models were more-or-less treated as heuristic futures by consultants and planners; it was not necessarily intended to represent a real future, but rather used a comparative assessment to examine how a potential future would affect each of the four roadway models. The results of the PARAMICs scenarios were then evaluated on four normative criteria or study lenses: transportation and infrastructure; urban design; environment, and; economics. These lenses were established against a backdrop of provincial legislative requirements, municipal political objectives and technical advice.

There are implications for how we should understand the use of the EA in light of these study lenses. While the EA is inundated with technical information, such information is of little guidance for either experts or elected officials without a normative structure to compare and rank technical data. The lenses provide a moral/political ordering such that data can be collated, assessed and stratified. This ordering was agreed upon by the city's staff and elected officials in the process of commissioning the EA report and sending out calls for proposals to consulting firms who would complete the various components of the EA report. While the EA is reasonably read as a technical document, it would be a mistake to exclude other readings including political/ moral readings, whereby expressions of ideals for the city are used to frame a reading of data. Indeed, the EA exists as a way of ensuring that such moral evaluation against competing interests is done in a fair and transparent manner, where 'fair' and 'transparent' are marked against standard, agreed-upon procedures properly applied and accounted for within the EA writing procedure.

\section{Political Scrutiny of the EA}


2014 saw the first version of the EA reach the floor of council's Public Works and Infrastructure Committee (PWIC) with the four options on how to proceed (Livey 2014). The EA draft report endorsed the Remove option, citing low costs, relatively low impact to commute times, and the opportunity to achieve 30 years of city planning vision by "reconnecting" the city with the shoreline of Lake Ontario and removing the physical barrier of the elevated expressway near the Don River. At this 2014 PWIC meeting, it appeared as though elected officials were also prepared to endorse this option to send to Council for a decision. However, on a last-minute basis, the property development company First Gulf proposed a fifth alternative, a so-called Hybrid option, that would, in theory, liberate land close to Lake Ontario by moving the Gardiner north, away from the lake, running alongside a corridor currently occupied by Canadian National Railway. This option maintained an elevated expressway link to the DVP, although planners were skeptical of the viability of the proposed curve between the East/West Gardiner and North/South DVP. They questioned if highway speeds could be maintained on a sharp, nearly 90-degree turn as illustrated in First Gulf's model. First Gulf has a vested interest in the future of the Gardiner as they own and plan to develop land directly east of the DVP/Gardiner junction, and require sections of the Gardiner to be removed in order to open that land for development ${ }^{3}$. Why the Hybrid option was proposed when this would have been accomplished with the once preferred Remove option remains a mystery to this day. While the First Gulf proposal was questionable - it was neither costed nor tested by appropriate officials - PWIC agreed to request city staff to investigate and report back in early 2015 .

In October 2014, John Tory was elected Mayor of Toronto. Part of Tory's platform was an endorsement of the Hybrid model, though at that point the Hybrid's plausibility was not yet known. In May 2015, the second EA draft was ready to be presented to PWIC and Council, this time predominately focusing on the once preferred Remove option and the new Hybrid option. When the EA was made publicly available, it was noted the Hybrid presented was remarkably similar to the previously dispreferred Maintain option. First Gulf's proposed connection between the DVP and Gardiner was indeed deemed to be too sharp and unsafe, and as such it was decided the Hybrid would have to follow the current path of the Gardiner, failing to liberate the valuable land in

3. At the time of writing, First Gulf has not formalized these development plans, but the company has been working with the city for a number of years preparing this proposal. For a background on First Gulf's involvement with the Gardiner decision, see Rider (2015). 
either the earlier version of the Hybrid proposal or the Remove option. The only significant change from the Maintain option was the removal of two eastern on/off ramps that abutted First Gulf's proposed development area, achieving the goal of opening up First Gulf's site but not reconnecting the city with the lake by moving or removing the elevated Gardiner structure. Additionally, the cost of the Hybrid was \$100mil more to build, and $\$ 500 \mathrm{mil}$ more to maintain over 100 years, than the Remove option (Livey 2015). Unlike the 2014 EA report that endorsed the Remove option, the 2015 EA report came with a split recommendation per study lens: for Urban Design, Economics, and Environment, the report preferred the Remove option. However, the report noted that there would be a three-minute increase in commute-times for most journeys into and out of Toronto's core during the morning peak hours if the Remove option were selected over the Hybrid ${ }^{4}$. The commute time differences were derived from the PARAMICs software simulations discussed above. On these grounds, the EA report endorsed the Hybrid option for the Transport and Infrastructure lens. These findings were to be presented to and discussed in a PWIC meeting on May $13^{\text {th }}, 2015$.

Curiously, Mayor Tory decided to supersede councils' scrutiny of the proposal, holding a press conference the day before PWIC was to debate the EA report. At this time, he announced his support for the Hybrid option. This was in direct contradiction to the City's chief planner, Jennifer Keesmaat, who had publicly and vociferously endorsed the Remove

4. One of the greatest ironies of Toronto council's treatment of the EA was the fixation on the three-minute figure. The report notes that, regardless of what option council decides upon, commute times were projected to raise a minimum of 30 minutes and upwards of an hour depending on destination/origin pairings. Thus, a driver travelling from the most extreme North-Eastern corner of the city to the Downtown core during the morning peak commuting hours was projected to have commute time increase from 57 minutes to 60 minutes if the Remove option were implemented. This projection was supposed on the grounds that Toronto's population is expected to dramatically increase by the 2031 build-out period, and as such there will be additional demand for road and transit use. Adding to this irony, all models, Hybrid, Remove, Maintain, Improve and Replace used the same scenario for future transit investment, i.e. the Hybrid would only achieve the 57-minute figure if the same public transit investment was made for the Remove option. However, by selecting the Hybrid option, Toronto Council effectively opted to spend an additional $\$ 100 \mathrm{mil}$ in limited fiscal resources on road infrastructure that, under the Remove option could have been available for proposed public transit infrastructure. Thus, if the scenario in the EA were to come to fruition, without additional investment in public transit, Toronto Council has likely endorsed an option that will result in higher commute times than the Remove option. 
option $^{5}$. Thus, a controversy took shape over the role of elected officials and civil servants with regards to who has rights to both attest the preference for municipal plans and speak publicly about them ${ }^{6}$. To this day, there has been no explanation for why Mr. Tory made the decision to preempt PWICs. In his speech, Mr. Tory contrasted his impression of Toronto's future with that of the EA report. Mr. Tory contested the premises of the Remove option (now dubbed Boulevard option to convey the 'grand boulevard' alignment of Lake Shore Boulevard, which would replace the Gardiner with Parisian style promenades, cafes, and waterfront access) asserting that he did not believe this plan could come to fruition, and the cost of doing so for automobile commuters would be too high (this will be examined in detail in the following section). PWIC spent a full day (9am until approximately 7: 30pm) scrutinizing the EA report before forwarding it to council without a recommendation ${ }^{7}$.

The EA was debated at council on June $10^{\text {th }}$ and $11^{\text {th }} 2015$. Council formed into rather predictable left wing (i.e. pro-Remove) and right wing (i.e. pro-Hybrid) factions with relatively few surprises. In the end, Mr. Tory was victorious in his Hybrid support by a narrow 24-21 margin. The vote was seen as damaging to both Mr. Tory himself and the plans in general, given Council's predilection for revisiting decisions and $\mathrm{Mr}$. Tory's failure, despite significant lobbying and vote whipping efforts, to attract a broader coalition (Dmitrieva 2015; Elliott 2015). Canada's

5. Keesmaat was not alone. During public consultation meetings, ex-Toronto Chief City Planner (and "world renowned city builder" as he was typically introduced at these meetings) Paul Bedford (with his associate Michael Kirkland, another city planner of expert reputation) strongly endorsed the Remove option. Mr. Bedford presented a series of case studies, focusing on the West Side Highway in New York City, the Embarcadero Freeway in San Francisco and the Cheonggyecheon Restoration Project in Seoul, South Korea, as "empirical evidence" of the positive results of removing elevated expressways in "world-class cities". Mr. Bedford stated Toronto would be "the laughing stock of the world" if it decided not to remove the Gardiner and recreate the space underneath the roadway in the public realm.

6. Perhaps as a reflex action from the years of Rob Ford's mayoralty, many newspaper journalists openly speculated that Keesmaat would be fired for her opposition to Mr. Tory's plans (i.e. Moore 2015; Gee 2015b). In the end, Ms. Keesmaat has retained her position, although her public campaigning has been diminished in the ensuing period, partially at the request (or imposition) of the Mayor's office (Pagliario 2015).

7. In a typical scenario, PWIC - a committee comprising elected officials appointed by the mayor with the remit of scrutinizing reports related to their portfolio - would forward a recommendation to council, suggesting the support of one option or another. Such an endorsement would typically be understood as an instruction on how to vote for elected officials not on the committee. 
newspaper of record, The Globe and Mail, greeted the decision with the scathing headline "A Sense of Civic Failure Hangs Over Gardiner Decision" (Gee 2015a) and noted that virtually no one could be happy with the outcome as it unfolded.

It is perhaps worth noting that "appropriate experts" (planners and consultants) recognized the EA as an exceptionally thorough and accurate document. It was "Peer Reviewed" by two outside consultancies to validate both the assumptions contained in the 2031 future scenario and the calculations that tested those assumptions ${ }^{8}$. Dillon is a company that is held in very high regard by municipalities and other planning consultancies and they have won several awards and commendations related to their work ${ }^{9}$. As such, there was a great deal of intrigue among observers and the press as to how such a thorough and credentialed report could be so easily disregarded by elected officials, who would certainly - almost to an individual at Toronto City Council - lack the technical proficiency to fully redress the report's methodology and techniques. The sociological question we might seek to ask in relation to the Gardiner decision is: "how did Toronto Council come to such divergent conclusions from their own appointed experts?" Or "How was this mistrust in the report arrived at?" Expert advice was relatively clear, pertaining to each of the study's four lenses. In terms of the "Economics" lens, the Remove option was preferred as it allowed council to sell valuable land currently occupied by the elevated expressway. This was expected to net the city upwards of $\$ 100 \mathrm{mil}$, which in turn could be used to pay a portion of the costs of building the new Lake Shore Boulevard that would replace the Gardiner. Also, Lake Shore Boulevard would be significantly less expensive to maintain than an elevated expressway. On the "Environment" lens, the Remove option was preferred as it created new public space for recreation, cleaner air as automobile traffic would be diverted or replaced by public transit options, better ground water management, less urban heat-sink effect due to new green space, and better cultural provisions through new buildings and services. On the "Urban Design" lens, planners imagined a waterfront space along the shoreline of Lake Ontario that corresponded with the official city plan for Toronto - creating space for residents to reconnect with the lake. Mixed-use commercial and residential buildings would create a dramatic and appealing street-

8. Peer review is discussed in the report itself. On top of those comments, urban planners who attended a number of public consultation sessions lauded the report as being of the highest quality.

9. The lobby of Dillon's Toronto office is decorated with a number of plaques and trophies related to these awards. Their website lists off a number of such accolades: http: //www.dillon.ca/about/awards-and-recognition 
scape that accented the public realm. "Transportation and Infrastructure" was the only lens to favour the Hybrid, on the grounds that, using the PARAMICs modelling software, commuting times in the year 2031 were projected to increase by 57 minutes in the most extreme case under the Hybrid, whereas in the Remove option that commute was projected to increase to 60 minutes (Livey 2015). While it may seem clear, from the content of the EA report, that the preferred option should most likely be Remove on the grounds that it is less expensive, more thoroughly meets the city's goals, reflects a more "urban" or "world class" plan, etc. councilors had difficulty accepting this vision for the future city. Much of this came down to the plausibility of these plans and the amount of trust councilors were willing to grant the projections made in the PARAMICs scenarios - could a software program adequately represent and predict how traffic would move in Toronto, given what elected officials know of the idiosyncrasies or particularities of Toronto drivers?

\section{Competing Versions of the Future, Ontological Certainty, and "Common SeNSE GeograPhY"}

A point of contention that emerged through the discussion between City Staff/Dillon Consultants and elected officials might be described, following Woolgar and Neyland (2013) as the ontological status of the EA report $^{10}$. Woolgar and Neyland discuss the complexity of deriving and agreeing upon the meaning of evidence pertaining to governing agendas (their example most relevant to this case being programs for assessing the efficacy of municipal waste collection). Here, a similar problem emerged in relation to the validity of the Dillon's future scenario projections, particularly the differences in commute times. One of the EA report's authors noted that, as this author discussed the report with elected officials, those elected officials expressed a desire for "concrete guarantees" that commute-time projections would actually occur as PARAMICs had suggested. This type of guarantee, looking fifteen or more years into the future, is not something any trained and competent planner or consultant would ever be willing to attest to. This stood as an obstacle between elected officials and planners who were attempting to derive meaning from, and resolve competing understandings of, what the EA model was meant to

10.I have no strong commitment to the notion of Ontology as it is generally treated in STS or SSK. Here, I take Ontology to be loosely tied to Garfinkel's assessment of the practices involved in creating objective evidence as a distinctly local or situated phenomenon subject to numerous practicalities, and one which is open to audit when removed from local circumstances (i.e. 1967; pp. 102-103). 
accomplish. Consultants and planners treat scenario models as comparative tools, or, as stated above, heuristics, that can be used to test different pathways against a constant future. While every effort is made to account for a realistic future, there is no way to know what will happen tomorrow or many years from now with absolute certainty. Planners and consultants are aware of this; some elected officials, perhaps, are not (or at least account for the inherent uncertainty of the future in a different manner than planners and consultants) ${ }^{11}$.

Absent a guarantee of the future scenario unfolding as planned, elected officials including Mr. Tory began to express skepticism of the EA report. Elected officials questioned the wisdom of trusting general models of Toronto commuting patterns from a computer simulation. In short, and in something approximating an amalgam of the terms various pro-Hybrid or skeptical councilors used, the methodology of the EA report was derived from more general models of driver behaviour that were then transposed onto the future roadway models. The question they could find no satisfactory answer for was: "can we be certain that these model drivers replicate the behaviour of real-life Toronto drivers?" or put differently, "can we trust the simulated driver to replicate the actual Toronto driver?"

In his speech on May $12^{\text {th }}, 2014$, Mr. Tory began by conveying a sense of priority related specifically to the City of Toronto - vehicular traffic congestion. Mr. Tory conveyed this priority stating “... I believe... we have to keep traffic moving in this city. Not just traffic but commerce as well." He asserts the idea of "keeping traffic moving" against the Hybrid model's continuous expressway link between the Gardiner and DVP. In Mr. Tory's estimation, without an ontologically certain future scenario whereby commuters and goods transporters are guaranteed not to be adversely affected by the broken expressway link, the risk of removing this link is too significant in light of locally shared priorities such as resolving traffic congestion. He continues by stating: "We have one of the worst congestion problems... in North America and there is little doubt in my mind that tearing down the Eastern section of the Gardiner would only make matters worse. Much worse." And further on: "I didn't get elected to make traffic worse. And let's be clear - removing that piece of the Gar-

11. Although it is beyond the scope of this article, it may be worth considering the relationship between authoritative stance and performativity of technical and scientific documents as discussed by Hilgartner (2000). The Gardiner EA report, and its treatment under examination by its authors, exhibit a number of features that might be understood as avoiding concrete attributions of authoritative performance, i.e. the reports' authors treat the report as inherently speculative, and although it is grounded by concepts such as 'best practice' and 'peer review', another aspect of 'best practice' in this type of exercise is avoiding expression of overconfidence in the conclusions of the report. 
diner will almost certainly make traffic worse." Mr. Tory appeals to common sense geographical understandings of roadway infrastructure: that continuous expressway links afford commute times that are exceeded by those of non-expressways. This is in juxtaposition to the EA report, which states that commute times are projected to get worse regardless of what option is chosen, and only marginally worse if the Remove option were to be selected. However, using common sense geographic notions like speeds associated with ring-road expressways, Mr. Tory begins to dismantle future projections that do not readily correspond to what-any-personwould-agree (c.f. Garfinkel 1967; pp. 76; 105-106) is commonsensically known about expressway systems.

Mr. Tory furthers the ontological destabilization of the EA report by referencing a second commute time assessment presented by an outside party that predicted a ten-minute - rather than three minute - difference in Remove rather than Hybrid option" ${ }^{12}$ : "While experts disagree on just exactly how much worse - one says three to five minutes, another says ten - there is no doubt that there will be a negative impact on commute times..." Here the differences in times are less important in themselves - that generally planners, consultants and politicians would concede that commute times can fluctuate anywhere from minutes to infinity depending on the day - than the destabilization of reliability the scenarios purport to be comprised - i.e. that different assessments indicate an untrustworthiness to computer simulations. If elected officials are not presented concrete, guaranteed scenarios and alternative assessments present conflicting data, the ontological status of the EA report degrades into uncertainty, except for the undoubted status of things inevitably getting worse.

Finally, Mr. Tory assails the idea that replacing the Gardiner with a "grand boulevard" is anything more than the flight and fancy of urban planners and consultants gone wild:

"The eight lane roadway that would replace the eastern section of the Gardiner would, for all intents and purposes, be a street level expressway. Any notions of sipping a coffee in a café next to a busy, congested eight-lane highway should be put out of your mind, because it's just not a reflection of reality. I mean, the traffic could just disappear or divert itself onto other streets. But ask yourself. Does that accord with common sense? Is that a likely scenario? Again I don’t believe so."

12.In actuality, both the City's own EA and the second report Mr. Tory references, conducted by the Transportation Research Institute at the University of Toronto (Baher et. al 2015) come to very similar conclusions. I do not wish to ironicize Mr. Tory's statements here; instead I intend to simply examine the practice of destabilizing the findings of the EA report against a backdrop of uncertainty and risk, for which he is ultimately accountable. 
Again Mr. Tory juxtaposes the inherent uncertainties of the EA report with alternative conceptions of future states of affairs. His instruction is quite simple: imagine the types of people who will use this roadway; imagine the types of things they do now (move quickly on an elevated expressway); imagine the probability for that to change given a change in road infrastructure. Mr. Tory here appeals to something of a knownin-common sociology or social geography of drivers; that residents of Toronto are mutually familiar with the types of drivers that currently use the easternmost section of the Gardiner, and that knowing what we know of these drivers, we cannot reasonably assume that they will respect the characteristics and "rules of the road" if the Remove option were chosen. In effect, the future Remove or boulevard option relies on a social assumption that, once the old highway is removed, users of the new boulevard - now cast as a "busy, congested eight lane surface highway" - will behave according to the rules and norms of grand boulevard traffic (i.e. slower speeds, less idling, respecting pedestrian crossings, etc.). Mr. Tory assures us this assumption is little more than the fantasy of utopian urban planners detached from the common-sense realities of urban life in Toronto. In short, Mr. Tory comes to the overarching conclusion that, due to a number of factors, the projections of Toronto's future according to appointed experts seems, against a backdrop of common-sense, untrustworthy.

What we should note here is that the arguments Mr. Tory makes are not, in some way, 'un-technical' or ignorant to the technical aspects of this report. Instead, Mr. Tory and other councilors supporting the $H y$ brid alternative were not willing to share the same orientation to the conclusions of the report that experts were on grounds of its technical limitations. It is not the case that experts were technical and elected officials were not, but that those councilors who expressed skepticism in the report's conclusions did so on the grounds that the report did not hold up to rather intense technical scrutiny, especially when elected officials began to layer-on background knowledge of their local geography and constituents the report did not explicitly address.

\section{Common Sense Geography and Elected Officials}

Ethnomethodologists have a long-standing interest in how members organize and make sense of their environments, including orientations to, or uses of, geographic concepts or concerns. This interest is expressed in two lines of inquiry: the first is how members organize and share knowledge of relevant geographic features or representations when giving directions (Psathas 1986), navigating in groups (Laurier and Brown 2006) 
or drawing and using maps (Liberman 2013). The second line deals with how members use geographic references or concepts in the course of talk-in-interaction, or to vet the plausibility of future plans. Drew (1978) analyzes how courtroom testimony involving reference to known-incommon geographic locations associated with religious groups (either Protestants or Catholics in Northern Ireland) informs hearers of the nature of accusations being leveled at a police constable thought to have not adequately responded to a religious riot. The use of place formulations allowed the hearers to make sense of the types of activities a group of people would be engaged in (either violently rioting or innocently looking-on) based on where that group had originated and the direction it was headed. Similarly, Eglin (1979; see also 1980) discusses competing accounts of either police brutality or appropriate police action (what Pollner, 1975, refers to as "reality disjunctures") and how accounts gain or lose credibility based on the physical space occupied by the observer in relation to the incident. Mair et. al $(2012 ; 2013)$ and Neville (2009) conduct similar studies of place reference and coordination of action in military close air support missions. Perhaps most relevant to the discussion of the Gardiner, McHoul and Watson (1984) discuss "commonsense geography" and its relationship to more formally organized or occasioned geography-specific accounts of how an "urban ecology" (pp. 290-291) might be organized. For McHoul and Watson, common sense knowledge is worked into subject knowledge (i.e. formal geographic knowledge) by interrogating the categorical features and predicates of building types and how those types relate to the specificities of just this space or just this region. For McHoul and Watson, formal geography-asurban-ecology is difficult to isolate from common sense understandings of, effectively, "how things fit together here":

... particles [of commonsense geographical reasoning] attest to the 'family resemblance' nature of commonsensically-known urban ecological areas, such that they may sometimes be seen as having multifarious characteristics, often convergent, often divergent, shading off into each other. In all, commonsense geographical constraints exhibit what, to use Wittgenstein's (1968, No. 66) words, appears as "a complicated network of similarities overlapping and criss-crossing: sometimes overall similarities, sometimes similarities of detail." (McHoul and Watson 1986: 293)

For McHoul and Watson "Members... are ceaselessly performing commonsense analyses of typical objects of their world, and the typical objects of place are no exception... common sense geography... is embedded in, and counts upon, a far broader communicative and interpretive procedure... which facilitates constant re-working of commonsense 
geography with reference to varying practical relevances" (ibid; 298). Moreover, following Schegloff (1972), it may be said that while formal (propositional) geographical knowledge exists and is used in such practical-technical exercises as predicting how the future of a city is likely to unfold, it is also the case that '... such a corpus [of knowledge] does not seem to form a rigid, invariant and strictly bounded conceptual grid, but instead is an open-textured domain, open to recombinations and at all points embedded in a generic domain of procedural knowledge which ties slivers of geographic knowledge to the occasions of its relevant use" (McHoul and Watson 1986; 297).

The consequences of common sense geography and the impact of common sense reasoning on formal geographic knowledge is dramatic when considered against the backdrop of public policy making, particularly to do with space and infrastructure. The formal assumptions of the Gardiner EA report rely on a great deal of informal or lay sociological theorizing about the nature of road users and how they may adapt to new and altered road infrastructure. Presuming that road users will cooperate with new road layouts, such that the visions of "Grand Boulevards" or "Open Green Public Spaces" can be realized relies on a model of road user that is willing to participate in such a scheme (i.e. treat the road as a Grand Boulevard and not an eight lane surface highway). Again referring to Schegloff (1972) we should note that particular social types (membership categories) are granted status (category predicates) in relation to what-may-be-known about a given social or geographic environment (see also Sharrock 1974):

“... most persons live... in a place in an environment of places, in a house, in a neighbourhood, in a "part of town"-which can be similarly talked of (and it is an important fact that some do not). Their place, and its environment of places, have characteristics, character, a population composition, etc. These categories are filled by persons with their particular situations, their house, their street, their neighbourhood, their part of town, their city, their state, etc., on which they are knowledgeable and can speak, while others can respond accordingly." (Schegloff 1972; 93 italics original)

To borrow Schegloff's example, when an individual is looking for a rock and roll club in New York City for which they know the name but not the street address, they may consult the "hippiest" looking person around, who it might be presumed would know more about the location of music venues than a "square" looking person. Equally, we might ask, who is most trustworthy (i.e. most likely to know the reality of...) the nature and characteristics of the population composition of this town, this electoral ward, this region, etc? It can certainly be argued that, in a 
representative democracy, persons selected from amongst the populace to stand as representatives of a constituency are equally granted rights to speak authoritatively (trustworthy-ly) about the nature of the people they represent, perhaps in a manner more deserving of trust than a software simulation controlled by 'experts' of relatively unknown origin, presenting a counter-intuitive finding. In this case, when elected officials were presented with something of a "formal model" of driver behaviour, devised by future scenario planning software, the question they sought to have answered was along the lines "can these formal models account for and replicate local nuances in driver behaviour?" or "can you guarantee Toronto drivers will act like the formal models you describe?" This type of question posed a problem for planners; anyone can predict how individuals might react to a road layout, but doing so with certainty, using software models or not, is not something that planning "best practice" permits. As such, planners and consultants, in effect, expressed a degree of skepticism in their own report (i.e. "it's only a model") and this was interpreted by elected officials as meaning "not necessarily a trustworthy model".

A number of intricacies for understanding processes of public planning for municipal infrastructure emerge as a result of this, and issues of trust associated with complex scenarios and practices of planning for the future, while gaining purchase, require some explication. First, we should note that, following Watson:

“... it must be said that trust as a first-order phenomenon has proved remarkably elusive. Part of the reason for this is that, because of its tacit character, trust is such a fugitive contextual phenomenon - it 'appears' in only a few contexts and 'disappears' in many others. Most frequently, it is a presumptive phenomenon and therefore tacitly attended to by members" (2009: 476)

I am relying here on a partially generous reading, inasmuch as reader and author both orient to tacit notions of trust and the situated practice of not trusting a report as being mutually apparent. Trust here is used to gloss a number of specific instances and objections to the EA report, and is primarily located in expressed skepticism about PARAMICs or the likelihood that Toronto drivers would respect a boulevard configuration. However, Watson goes on to state that "For Garfinkel, trust has its 'natural home' amongst fundamental considerations such as... sense-making practices... that is, in the ordered properties of achieved intersubjectivities of everyday life." (ibid: 480). As a result, when such intersubjectivity is not achieved, as is the case with the perspectives held by either city planners or elected officials in Toronto, we can see a strain on such 
relationships for which trust is a "constituent feature". And further on: "We might suggest that 'trust', as an ordinary, laic concept, is situated in relation to other concepts such as 'undoubting', 'unquestioning'." (ibid: 487) so when elected officials do call into question the validity of expert advice, they are tangibly and demonstrably exercising orientations of mistrust (to varying degrees and with varying consequences) in the data, methods or findings subscribed to by those experts.

What I would like to note here is that the nature of the mistrust expressed here is not that of blind ideology trumping technical information, misapprehension of the data presented by experts, or some failure to find the correct experts among competitors ${ }^{13}$. Instead, the nature of the knowledge controversy stems from a mistrust in the capacity for software simulations to adequately capture local nuances to things like driver behaviour. This is not a failure to understand the evidence, it is a disagreement about the extent to which the evidence is valid (trustworthy) for drawing the conclusions to which experts attest (c.f. Shapin and Schaffer 1985).

\section{Conclusion: On Expertise, Trust, and Making Sense of Data}

We have seen from Jenkings and Barber (2004; 2006), Yeo (2012) and Ramp and Harrison (2012) that any effort to simply replace "ideological" decisions with "evidence based" decisions is problematic on several grounds, not the least of which is that the nature of evidence is inevitably tenuous, conditional and open to interpretation. We might also note that following Wynne (2003) or Jassanoff (2003) that deciding what types of decisions are to be considered purely on "technical merits" or what counts as "technical information" is itself a "political" decision. However, perhaps a more pertinent and expansive theoretical point can be made here, by use of notions of trust and the idea that trust is properly a constitutive feature (Garfinkel, 1963) of the relationship between elected official and expert. In other words, academic approaches - mentioned above - that treat deviations from expert advice as a dereliction of electoral responsibilities presuppose that it is right or correct for elected of-

13.It may be argued there are some aspects of this, pertaining to the aforementioned competing assessments offered by a second, outside expert report written at the University of Toronto (see footnote 9). However, even without this report, there is still a great deal of skepticism or mistrust among councilors about the EAs conclusions - if it is indeed reasonable to trust the commute-time differences regardless of their competing versions. At most, this is a further ontological destabilizing feature of the debate, rather than a sincere complexity in coming to terms with what the future may hold. 
ficials to trust expert advice. I see no reason to take this to be the case. In fact, this seems to assume that elected officials and experts are, in effect, in the same 'game' (c.f. Long 1958) or are occupied with the same concerns. We might also draw a completely different conclusion, such as that described by Rawls, summarizing Garfinkel:

Garfinkel argues that '[o]ne may see this if the terms 'scientist' and 'practical man' are used to designate ways of attending to a world rather than to designate concrete persons." The "scientist," he points out, will see one thing - the "practical man" another. There is no conflict, because the things they see live in different worlds like "apples and oranges" in the old saying. But, the differences in what they see are such as to prevent their talking about the "same" world, which is consequential and must be taken into account.(Rawls 2008: 23)

If the elected official is charged with representing the interests of the "practical man", is it appropriate to relinquish ground to "scientists" or other technical experts whose perspectives contrast with other ways of attending to the world? In instances where expert advice is tenuous or supported by assumptions that are not necessarily held-in-common or easily justified, it would be hard to blame elected officials for expressing uncertainty in decision-making.

The Gardiner stands as a dramatic representation the relationship between trust and expertise in a number of respects. First, it is fairly certain the evidence presented in support of removing the Gardiner was never going to receive a hearing by Toronto City Council on the grounds of that technical evidence alone (see Preville 2015). No matter how compelling the case and evidence for any of the options, each had to be weighed not only against technical merits, but also merits related to the perceived desires of constituents and the risks elected officials would be putting them under if they chose to accept the conclusions of the EA. Elected officials may approach their decision-making authority in a number of different ways, but those who do so without regard for their constituents' views and opinions are perhaps less likely to retain their positions as long as others who do.

Secondly, while members of the category "expert" in relation to city planning will grant certain degrees of certainty or trust to future scenario planning exercises within a certain framework of meaning and understanding, it is not incumbent upon elected officials or other auditors to share such subscriptions. In fact, a strong argument could be made that it would be irresponsible to do so. Instead the elected official can retain a role whereby s/he evaluates the relative merits of such technical assessments and holds in check the ambitions of those whose notions of 
progress or propriety (in other words, what risks are worth taking) may differ from those of the constituency.

This takes us to the third relevant point of politicians' work; that risks, such as removing a significant piece of public infrastructure, areor-are-not worth taking only inasmuch as the assessments of those risks are deemed trustworthy and as they relate to what version of a future state of affairs envisioned by a policy agenda is a desired future, especially when weighed against other costs. As is the case here, the cost of having a "Grand Boulevard" future scenario is outweighed in Toronto City Council's account by the cost of such a boulevard being largely inaccessible due to a fear of vehicle traffic congestion, or not being treated appropriately by its users.

As I proposed at the beginning of the article, one question academics might ask of Toronto city council's decision to endorse the Hybrid alternative for the Gardiner Expressway (as well as other public policy decisions), against nearly all expert provided advice, is: "What aspect of expert advice did elected officials not understand that led them to such a contradictory conclusion?" This is a pertinent question that seems reasonable to ask, although it is premised on the assumption that elected officials are breaching a trust held between themselves and experts by not following expert guidance, and that doing so is either untechnical or unscientific. There may be very good reasons for elected officials to solicit and adhere to expert guidance, depending on the particular decision at hand. Assuming expert advice is naturally or inherently good advice places the political decision-making process outside of the realm of the elected official's judgement. Equally, assuming elected officials are not using "technical" or "scientific" judgment presumes too little of the activities of elected officials (c.f. Sharrock, 1974). Instead of asking, in effect, "what is wrong with these elected officials?" sociological analysis of "how did elected officials publicly account for this decision?" or "what aspects of just-this-evidence did elected officials not trust?" provides us insight into potential deficiencies held elsewhere - that perhaps experts are not beyond reproach. Even if it is the case that our preference is, or should be, for expert-guided decision-making processes to be preferential to "ideological" decisions (or whatever other description we might turn to), understanding how to communicate the conditions of trustworthiness to elected officials, or seal off rhetorical avenues from which elected officials may assail the trustworthiness of such evidence, seems more likely to lead to decision-making outcomes where elected officials and experts arrive at similar or congruent conclusions. 


\section{REFERENCES}

Aucoin, P. 1990. Administrative Reform in Public Management: Paradigms, Principles, Paradoxes and Pendulums. Governance: An International Journal of Policy and Administration, 3(2): 115-137.

Baher, Abdulhai, Matt Roorda and Eric Miller. 2015. Assessment of the Gardiner East Tear Down: Final Presentation. Faculty of Applied Science \& Engineering, Transportation Research Institute. University of Toronto. May 6. Accessed 20 May 2015 at http: //www.cp24.com/polopoly_ fs/1.2363519!/httpFile/file.pdf

Blum, Alan F. and Peter McHugh. 1971. "The Social Ascription of Motives". American Sociological Review. 36(1): 98-109.

Boehm, M., Bowman, D. and Zinn, J. O. 2013. Survey Research and the Production of Evidence for Social Policy. Social Policy and Society 12(2): 309-318.

Church, Elizabeth. 2013. Clock is Ticking for Decision on Gardiner Expressway, Official Says. Globe and Mail. Toronto, Ontario, April 2. Accessed 15 July 2015 at http: //www.theglobeandmail.com/news/toronto/ clock-is-ticking-for-decision-on-gardiner-expressway-official-says/ article10707554/

Collins, Harry. 2010. Tacit and Explicit Knowledge. Chicago, IL: University of Chicago Press.

Collins, Harry. 2014a. Are We All Scientific Experts Now? Cambridge, UK: Polity.

Collins, Harry. 2014b. Rejecting Knowledge Claims Inside and Outside Science. Social Studies of Science. 44(5): 722-735.

Collins, Harry and Robert Evans. 2002. The Third Wave of Science Studies: Studies in Experience and Expertise. Social Studies of Science. 32(2): 235-296.

Collins, Harry and Robert Evans. 2007. Rethinking Expertise. Chicago, IL: University of Chicago Press.

Dale, Daniel. 2011. Giorgio Mammoliti: Political Provocateur turned Rob Ford Spokesman. The Toronto Star. August 13. Accessed 27 September 2015 at http: //www.thestar.com/news/gta/2011/08/13/giorgio_mammoliti_ political_provocateur_turned_rob_ford_spokesman.html

Dmitrieva, Katia. 2014. Toronto Votes to Keep Gardiner Expressway Intact. Bloomberg Business. New York, NY. June 12. Accessed 12 June 2015 at http: //www.bloomberg.com/news/articles/2015-06-11/toronto-votes-tokeep-gardiner-expressway-intact

Drew, P. 1978. Accusations: The Occasioned Use of Members' Knowledge of 'Religious Geography' in Describing Events. Sociology. 12(1): 1-22. 
Eglin, Peter. 1979. "Resolving reality disjunctures on Telegraph Avenue: a study of practical reasoning." Canadian Journal of Sociology/Cahiers canadiens de sociologie: 359-377.

Eglin, Peter. 1980. Culture as Method: Location as an Interactional Device. Journal of Pragmatics, 4(2): 121-135.

Elliott, Matt. 2015. Mayor John Tory Trades Credibility for Concrete with Gardiner Decision. Metro. Toronto, Ontario. June 12 Accessed 12 June 2015 at http: //www.metronews.ca/views/toronto/torys-toronto-mattelliott/2015/06/12/mayor-john-tory-trades-credibility-for-concrete-withgardiner-decision.html

Epstein, Steven. 1996. Impure Science: AIDS, Activism, and the Politics of Knowledge. Berkeley, CA: University of California Press.

Garfinkel, Harold. 1963. 'A Conception of, and Experiments with, "Trust" as a Condition of Stable, Concerted Actions. in O. J. Harve (ed.) Motivation and Social Interaction. New York, NY: Ronald Press.

Garfinkel, Harold. 1967. Studies in Ethnomethodology. Englewood Cliffs, NJ: Prentice Hall.

Garfinkel, Harold. 2002. Ethnomethodology's Program: Working Out Durkheim's Aphorism. Lanham, MD: Rowman and Littlefield.

Gee, Marcus. 2015a. A Sense of Civic Failure Hang Over Gardiner Decision. The Globe and Mail. Toronto, Ontario. June 11. Accessed 12 June 2015 at http: //www.theglobeandmail.com/news/toronto/a-sense-of-civic-failure-hangs-over-gardiner-decision/article24931010/

Gee, Marcus. 2015b. Jennifer Keesmaat's Vocal Advocacy a Refreshing Change at City Hall. The Globe and Mail. Toronto, Ontario. June 15. Accessed 16 June 2015 at http: //www.theglobeandmail.com/news/toronto/jennifer-keesmaats-vocal-advocacy-a-refreshing-change-at-city-hall/article24973730/

Goldsbie, Jonathan. 2015. So About That Mysterious Gardiner Poll... Now Toronto. Toronto, Ontario. June 11. Accessed 11 June 2015.

Hacker, P. M. S. 2007. Human Nature: The Categorical Framework. Oxford, UK: Blackwell.

Harper, Richard, Dave Randall and Wes Sharrock. 2016. Choice: The Sciences of Reason in the $21^{\text {st }}$ Century A Critical Assessment. Cambridge, UK: Polity.

Head, B. W. 2008. Three Lenses of Evidence-Based Policy. The Australian Journal of Public Administration, 67(1): 1-11.

Hilgartner, Stephen. 2000. Science on Stage: Expert Advice as Public Drama. Stanford, CT. Stanford University Press.

Jasanoff, Sheila. 2003. Breaking the Waves in Science Studies: Comment on H. M. Collins and Robert Evans, 'The Third Wave of Science Studies', Social Studies of Science, 33(3): 389-400. 
Jasanoff, Sheila. 2004. The idiom of co-production. In Sheila Jasanoff (ed.) States of Knowledge: The Co-Production of Science and Social Order. London, UK: Routledge.

Jenkings, K. Neil and Nick Barber. 2004. What Constitutes Evidence in Hospital New Drug Decision Making? Social Science \& Medicine. 58(9): 17571766.

Jenkings, K. Neil and Nick Barber. 2006. Same Text Different Meanings: Transformation of Textual Evidence in Hospital New Drugs Committees. Text \& Talk. 26(2): 169-189.

Knorr, Karin D. 1976. Policy-makers use of social science knowledge: symbolic or instrumental?. Institut für Höhere Studien.

Laurier, Eric, and Barry Brown. 2008. "Rotating maps and readers: praxiological aspects of alignment and orientation." Transactions of the Institute of British Geographers 33(2): 201-216.

Liberman, Kenneth. 2013. More Studies in Ethnomethodology. New York, NY: SUNY Press.

Livey, John. 2014. Staff Report: Gardiner Expressway and Lake Shore Boulevard East Reconfiguration Environmental Assessment (EA) and Integrated Urban Design Study. Toronto, ON: City of Toronto. Accessed 17 December 2014 at http: //www.toronto.ca/legdocs/mmis/2014/pw/bgrd/ backgroundfile-67146.pdf

Livey, John. 2015. Staff Report: Gardiner Expressway and Lake Shore Boulevard East Reconfiguration Environmental Assessment (EA) and Integrated Urban Design Study. Toronto, ON: City of Toronto. Accessed 10 May 2015 at http: //www.toronto.ca/legdocs/mmis/2015/pw/bgrd/backgroundfile-79902.pdf

Lynch, Michael and Simon Cole. 2005. Science and Technology Studies on Trial: Dilemmas of Expertise. Social Studies of Science. 35(2): 296-311.

Mair, Michael, Patrick G. Watson, Christopher Elsey and Paul V. Smith. 2012. War Making and Sense-Making: Some Technical Reflections on an instance of 'Friendly Fire'. British Journal of Sociology. 63(1): 75-96

Mair, Michael, Christopher Elsey, Patrick G. Watson and Paul V. Smith. 2013. Interpretive Asymetry, Retrospective Inquiry and the Explication of Action in an Incident of Friendly Fire. Symbolic Interaction. 36(4): 398-416.

McHoul, A. W., \& D. R. Watson. 1984. Two axes for the analysis of 'commonsense' and 'formal' geographical knowledge in classroom talk. British Journal of Sociology of Education, 5(3): 281-302.

Monahan, M. 2010. The Complexity of Evidence: Reflections on Research Utilisation in a Heavily Politicised Policy Area. Social Policy and Society, 9(1): 1-12.

Moore, Oliver. 2015. Toronto Chief Planner Opposes Mayor, Seeks Eastern Gardiner Removal. The Globe and Mail. Toronto, Ontario. May 22. Accessed 
23 May 2015 at http: //www.theglobeandmail.com/news/toronto/torontos-chief-planner-calls-for-eastern-gardiner-removal/article24566834/

Nevile, Maurice. 2009. "You Are Well Clear of Friendlies": Diagnostic Error and Cooperative Work in an Iraq War Friendly Fire Incident. Computer Supported Cooperative Work. 18(2/3): 147-173.

Pagliaro, Jennifer. 2015. Gardiner Road Rage Sidelines Toronto's Chief Planner. The Toronto Star. Toronto, Ontario. June 9. Accessed 30 November 2015 at http: //www.thestar.com/news/city-hall-blog/2015/06/gardiner-roadrage-sidelines-toronto-s-chief-planner.html

Peters, G. B. and Pierre, J. 1998. Governance without Government? Rethinking Public Administration. Journal of Public Administration Research and Theory, 8(2): 223-243.

Pielke, Roger. 2007. The Honest Broker: Making Sense of Science in Policy and Politics. Cambridge, UK: Cambridge University Press.

Pollner, Melvin. 1975. 'The Very Coinage of Your Brain': The Anatomy of Reality Disjunctures. Philosophy of the Social Sciences. 5(3): 411-430.

Porter, Theodore M. 1995. Trust in Numbers: The Pursuit of Objectivity in Science and Public Life. Princeton, NJ. Princeton University Press.

Preville, Philip. 2015. Why the Gardiner Decision, Whatever it is, Won't be "Evidence Based". Toronto Life. June 9. Accessed 10 June 2015 at http: //torontolife.com/city/gardiner-evidence-philip-preville/

Psathas, George. 1986. Some Sequential Structures in Direction-Giving. Human Studies. 9(2-3): 231-245

Ramp, W., \& Harrison, T. W. 2012. Libertarian populism, neoliberal rationality, and the mandatory Long-form Census: Implications for sociology. $\mathrm{Ca}$ nadian Journal of Sociology/Cahiers canadiens de sociologie, 37(3): 273-294.

Rhodes, R. A. W. 1996. The New Governance: Governing without Government. Political Studies, 44(4): 652-667.

Rhodes, R. A. W. 2005. 'Everyday Life in a Ministry: Public Administration as Anthropology' American Review of Public Administration. 35(3): 3-25.

Rider, David. 2015. Gardiner Intersections: Developer First Gulf, its Lobbyists, the Mayor's Office and a Poll. The Toronto Star. June 10. Accessed 2 December 2015 at http: //www.thestar.com/news/city-hall-blog/2015/06/ intersections-on-the-gardiner-developer-first-gulf-its-lobbyists-the-mayor-s-office-and-a-poll.html

Schegloff, E. A. 1972. Notes on a Conversational Practice: Formulating Place. In Sudnow, David (ed.) Studies in Social Interaction. Pp. 75-119. New York, NY: The Free Press.

Shapin, Steven and Simon Schaffer. 1985. Leviathan and the Air Pump: Hobbes, Boyle, and the Experimental Life. Princeton, NJ: Princeton University Press. 
Sharrock, W. W. 1974. On Owning Knowledge. In Roy Turner (ed.) Ethnomethodology: Selected Readings. Middlesex, UK: Penguin Education.

Slaughter, Graham and Alyshah Hasham, 2012. Gardiner Expressway Concrete Falls on Mercedes at Yonge St. and Lake Shore Blvd. Toronto Star. Toronto, Ontario, July 25. Accessed 17 July 2015 at http: //www.thestar. com/news/gta/2012/06/25/gardiner_expressway_concrete_falls_on_ mercedes_at_yonge_st_and_lake_shore_blvd.html

Smallman, Melanie. 2016. "Public Understanding of Science in turbulent times III: Deficit to dialogue, champions to critics." Public Understanding of Science. 25(2): 186-197.

Stoker, G. 1998. Governance as Theory: Five Propositions. International Social Science Journal, 50(155): 17-28.

Van Hulst, Merlijn. 2008. Town Hall Tales: Culture as Storytelling in Local Government. Rotterdam, Netherlands: Eburon.

Vaughan, Diane. 1996. The Challenger Launch Decision: Risky Technology, Culture, and Deviance at NASA. Chicago, IL: University of Chicago Press.

Vaughan, Diane. 2006. NASA Revisited: Theory, Analogy, and Public Sociology. American Journal of Sociology. 112(2): 353-393.

Watson, Patrick G. 2014. Can Politicians Afford Knowledge? Evidence as Affordance in New Governance Oversight Arrangements. Administration \& Society. DOI: 10.1177/0095399714548271

Whatmore, Sarah J. 2009 Mapping knowledge controversies: science, democracy and the redistribution of expertise. Progress in Human Geography. 33(5): 587-598.

Winch, G. M. \& Maytorena, E. 2009. Making Good Sense: Assessing the Quality of Risky Decision Making. Organization Studies, 30(2): 181-203.

Winch, Peter. 1958. The Idea of a Social Science and its Relation to Philosophy. London, UK: Routledge \& Kegan Paul.

Woolgar, Steve, and Daniel Neyland. 2013. Mundane Governance: Ontology and Accountability. Oxford, UK: Oxford University Press.

Wynne, B. 1996. May the Sheep Safely Graze? A Reflexive View of the ExpertLay Knowledge Divide. In S. Lash, B. Szerszynski and B. Wynne (eds) Risk, Environment and Modernity: Toward a New Ecology. Thousand Oaks, CA: Sage.

Wynne, B. 2003. Seasick on the Third Wave? Subverting the Hegemony of Propositionalism: Response to Collins \& Evans (2002). Social Studies of Science, 33(3), 401-417.

Yanow, Devora. 2006. Talking About Practices: On Julian Orr's Talking About Machines. Organization Studies, 27(12), 1743-1756. 
Yeo, Michael. 2012. The Rights of Scientists and the Rights of Politics: Lessons from the Long-Form Census Controversy. Canadian Journal of Sociology. 37(3): 295-317.

Young, K., Ashby, D., Boaz, A. \& Grayson, L. 2002. Social Science and the Evidence-Based Policy Movement. Social Policy and Society, 1(3): 215224.

Patrick G. Watson is assistant professor of Criminology at Wilfrid Laurier University. His research examines evidence, perception, and law, in assorted government settings including military inquiries, courts of law, and local government meetings. He pursues these topics using sensibilities from ethnomethodology and science and technology studies. In $2010 \mathrm{He}$ completed his $\mathrm{PhD}$ in sociology at the University of Manchester, UK. He is currently preparing a monograph on the Gardiner decision and the software employed therein, as well as the use of video evidence employed in trials of police officers accused of murder, manslaughter, or other forms of misconduct.

E-Mail: pwatson@wlu.ca 
76 C) Canadian Journal of Sociology/Cahiers canadiens de sociologie 43(1) 2018 